\title{
NOTE
}

1. Either Lear was misremembering here, or Dickens had been 'shooting a line'. There is not the slightest reason to believe that John Dickens was intimate, at this time, with any of these actors.

\section{Prospects Improving}

\author{
JOHN PAYNE COLLIER
}

From An Old Man's Diary: Forty Years Ago (1872) pt 1v, pp. 12-15. Collier (1 7891883 ), scholar and journalist, was asked (in 1833 , he says, but 1834 is more probable) to help Dickens obtain a post on the Morning Chronicle, a much superior journal to the True Sun, on which he was then working. Dickens's uncle, John Barrow, assured Collier that his 'clever nephew' was not only a good reporter but also 'cheerful company and a good singer of a comic song' - as appeared when they met over a dinner to discuss the matter.

... many comic songs were sung . . . two by Dickens, who would not make the attempt until late in the evening, and after a good deal of pressing. One of them was called The Dandy Dog's-meat Man, then much in vogue with the lower classes, and the other was an effusion by Dickens himself [beginning 'Sweet Betsy Ogle']. ... We were all very merry, if not very wise, unless merriment be taken as another sort of wisdom. . . . I may here add, that soon after [his appointment to the Chronicle] I observed a great difference in C. D.'s appearance and dress; for he had bought a new hat and a very handsome blue cloak, with black velvet facings, the corner of which he threw over his shoulder à l' Espagnol. I overtook him in the Adelphi, and we walked together through Hungerford Market, where we followed a coal-heaver, who carried his little rosy but grimy child looking over his shoulder; and C.D. bought a halfpenny worth of cherries, and, as we went along, he gave them one by one to the little fellow without the knowledge of the father. C. D. seemed quite as much pleased as the child. He informed me, as we walked through it, that he knew Hungerford Market well, laying unusual stress on the two first syllables. He did not affect to conceal the difficulties he and his family had had to contend against. 